\title{
EDITORIAL
}

\section{Mental health nursing in Europe: a global challenge, in Czech Republic too}

Mental health disorders are one of the biggest public health challenges in Europe. It is a silent problem, with a heavy burden of associated disability, including problems such as depression, anxiety and schizophrenia like a significant proportion of the causes of early retirement due to disability in Europe, with high economic and social weight.

The European Mental Health Action Plan 2013-2020 summarizes in a very practical way the goals, values and vision that incorporate the major challenges for mental health in Europe (justice, empowerment of patients and families). This commitment to de-institutionalization and the development of community-based mental health services remains alive across Europe. (WHO, 2015) Reality also shows that the social stigma associated with mental illness is a monster that is difficult to fight and that the resulting discrimination reduces the demand for mental health care.

Europe needs a health system more committed to the social outcomes of integration than to the economic costs of care and a system that integrates seamless responses is essential for access for people with mental illness.

From this context emerges new realities, new interpretations and new challenges for mental health intervention, whether in the social, family, community or spiritual sphere (spiritual care refers to the recognition of a person's sense of meaning and purpose for life, which may or may not be expressed by formal religious beliefs and practices being by nature cross-cutting and multicultural). Instead of a normalized population, there is today in Europe a society of multi-ethnic models (Rosas, 2007) that require differentiated approaches from health services.

I leave you with some of the challenges that I recently presented in Brussels at the AIM Conference - The future of mental health (Cordeiro, 2018): Mental health at school; Mental health at workplace; Mental health and spirituality; Mental health and transculturality; Mental health and migrations and minorities; Mental health on continuity care; Mental health and new medications; Stigma and discrimination; "The black dog - Depression and suicide".

In the Czech Republic, data associated with the reality of psychiatry and mental health are described (Pec, 2018) and refer to a predominance of hospital care over community care, too long periods of hospitalization and institutionalization of patients, frequent relapses, low efficacy and high cost of care, low conditions in patient care services and low ratios of nurses per patient. Recently, the Czech Ministry of Health has decided to use 2014-2020 ESF funds partly for psychiatric care and created the Strategy for the Reform of Psychiatric Care, which was issued in October 2013 (MZČR, 2013).

According to Pec (2018) the global aim of the Strategy (in Czech Republic) is to improve the quality of life of people with mental illness, and its strategic aims are to reduce stigmatisation, to increase the satisfaction of patients and the efficacy of psychiatric care, to increase inclusion of patients into the community, to improve the linkage between health and social services, and to humanise psychiatric care.

This strategy highlights the importance of nurses in mental health teams, also pointing out innovative care methodologies such as case management, crisis intervention and community-based care.

A global challenge for nursing in general, and for nursing in the Czech Republic in particular.

Assoc. Prof. Raul Cordeiro, PhD, MSc, RN

Polytechnic Institute of Portalegre, School of Health, Portugal

\footnotetext{
References

Cordeiro RA. Setting the scene: the panorama of mental health in Europe. In: AIM Conference - The future of mental health in Europe. Brussels: AIM; 2018.

MZČR. Strategie reformy psychiatrické péče. 2013 [cited 2019 Oct 10]. Available from: http://reformapsychiatrie.cz/wpcontent/uploads/2013/10/SRPP_publikace_web_9-10-2013.pdf (in Czech)

Pec O. Mental health reforms in the Czech Republic. BJPsych International. 2019;16(1):4-6.

Rosas J. Sociedade multicultural conceitos e modelos. Relações Internacionais. 2007;14:47-56. (in Portuguese)

WHO. The European Mental Health Action Plan 2013-2020. WHO Regional Office for Europe; 2015. [cited 2019 Oct 10]. Available from: http://www.who.int/iris/handle/10665/175672
} 